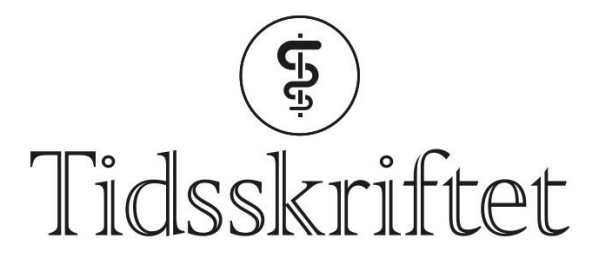

DEN NORSKE LEGEFORENING

\title{
Viktig vaksinasjon
}

TIDLIGERE I TIDSSKRIFTET

\section{JULIE DIDRIKSEN}

E-post: julie.didriksen@tidsskriftet.no Tidsskriftet

Kopper er en av historiens mest fryktede sykdommer. WHO erklærte sykdommen utryddet i 1980, etter en vellykket og omfattende vaksinasjonskampanje. I Tidsskriftet nr. 16/17 i 1925 kunne vi lese om situasjonen i Detroit i 1924, altså lenge før WHO-kampanjen kom i gang. Den amerikanske byen hadde i flere år vært hjemsøkt av utbrudd. Det var en tydelig sammenheng mellom manglende vaksinasjon og alvorlig sykdom og død (Tidsskr Nor Lægeforen 1925; 45: 842-4).

\section{Smallpox in Detroit 1924}

H. F. VANGHAN, C. E. BUCK, B. BERNBAUM, E. H. BOERTH. CITY heALTh. MONTHLY BULLETIN. DETROIT DEPARTMENT OF HEALTH. APRIL-MAY 1925. VOL. VIII, NR. 3.

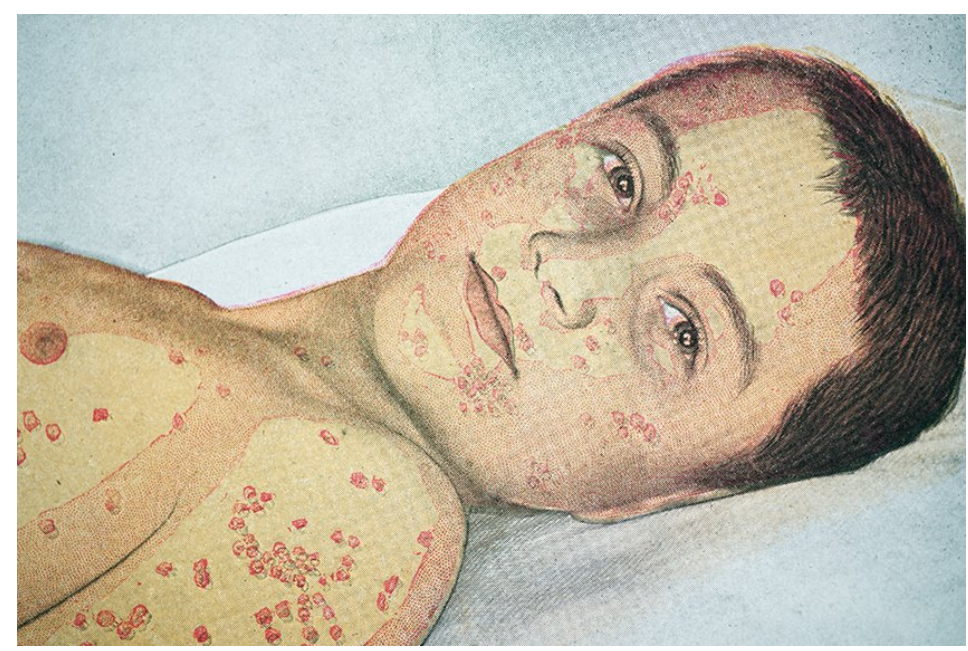

Illustrasjon: VintageMedStock/Alamy Stock Photo

I 1924 hadde man i byen Detroit 1610 tilfælder av kopper, som frembød meget av interesse. Detroit har i de siste 10 aar stadig været hjems $ø$ kt av kopper, hvorav antallet av tilfælder i 1920 utgjorde hele 1125. Disse koppetilfælder har dog forløpet meget let, saa at der f. eks. i 1920 kun var 2 koppedødsfald. I 1924 skiftet sygdommen karakter og medførte i alt 163 dødsfald. Sygdommen optraadte dette aar med to repriser eller epidemier. Den ene av disse faldt mellem 13de og 1 ste september. Den medførte 784 tilfælder og 139 dødsfald og er gjort gjenstand for nøiere studium.

Skjønt sygdommen optraadte i alle aldre, var den hyppigst i aldersgruppen 20-30 aar. Det 
var meget paafaldende, at skolealderen var næsten forskaanet for sygdommen, fordi netop denne alder saa ofte ellers er mest utsat. Forklaringen for dette maa søkes i den omstændighet, at man ved epidemiens begyndelse øieblikkelig indførte tvungen vakcination paa skolerne. De forældre, som negtet at la sine barn vakcinere, maatte holde dem hjemme fra skolen i 21 dager. Av de 28 skolebarn, som blev angrepet, var de 26 ikke blit vakcinert, fordi dere forældre hadde valgt at holde dem hjemme de 21 dager. Blant de syke var 124 eller 5,82 pct. angrepet av hæmorragiske (sorte) kopper, 219 eller 27,93 pct. av konfluerende kopper og 441 eller 56,25 pct. av varioloider. Dødeligheten i den første gruppen var overordentlig stor, 99,19 pct., mens den i 2 den og 3 dje gruppe var henholdsvis 4,11 pct. og 1,59 pct.

Av de 28 skolebarn, som blev angrepet, var de 26 ikke blit vakcinert

I de tilfælder, hvor smittekilden lot sig paavise, konstaterte man, at sygdommens hæmorragiske form kunde foranledige tilfælder av baade hæmorragiske kopper, konfluerende kopper og varioloider. Omvendt saa man ogsaa, at varioloider ved smitte kunde gi oprindelse baade til konfluerende og sorte kopper. Med hensyn til sygdommens smitsomhet viste det sig, at av 662 personer, som hadde utsat sig for smitte ved intmit samvær med patienter lidende av sorte kopper, fik 8 pct. kopper, av 935 personer, som paa samme maate hadde været utsat for smitte med konfluerende kopper, fik 6,63 pct. kopper, mens 4,65 pct. av 1977 personer blev smittet ved samkvem med syke lidende av varioloider.

Hvad angaar vakcinationsforholdene hos de smittede, er at bemerke, at blant samtlige angrepne var 85,36 pct. aldri blit vakcinert med positivt anslag, mens 14,64 pct. hadde gamle vakcinationsmerker. Blant disse hadde dog ingen været vakcinert med positivt anslag i de siste 5 aar. Av dem, som døde, var 88,48 pct. overhodet aldrig blit vakcinert med positivt anslag, mens de øvrige ikke var vakcinert med positivt anslag i de siste 10 aar.

Epidemien beregnes at ha kostet byen direkte 127854 dollar, mens man ikke kan beregne værdien av de 163 menneskeliv, som gik tapt. Den tapte arbeidstid for syke og internerte utgjorde til sammen 163 aar, 8 maaneder og 17 dager.

Epidemiens bekjæmpelse blev ledet paa en yderst energisk maate. Man var ikke i tvil om, at grunden til dens ophør først og fremst maatte søkes i, at befolkningen blev gjennemvakcinert. I løpet av $1 \frac{1}{2}$ aar utførtes ca. 800 ooo vakcinationer. Hele distrikter blev avspærret med politi, som hindret al passage til og fra for alle som ikke kunde fremvise vakcinationsattest, og læger avsøkte husene systematisk for at vakcinere. I et av sykehusene utførtes der ca. 3000 vakcinationer av patienter, som til dels led av alle mulige infektionssygdommer (erysipelas, impetigo, scabies, scarlatina, tuberkulose o.s.v.), uten at man saa nogen komplikationer. Blandt disse var ogsaa 773 barselkvinder og 676 nyfødte barn, som blev vakcinert 1ste eller 2den levedag. Man trak derfor den slutning, at der overhodet ikke eksisterte nogen kontraindikation mot vakcination.

Der er kun en konklusion, som vor forfærdelige erfaring gir anledning til, og det er, at vi må fremtvinge vakcination

Epidemien er meget lærerik, fordi den atter fastslaar, at koppene fremdeles kan optræ like ondartet som i gamle dager, og fordi den har levert nyt og vel bearbeidet materiale til belysning av vakcinationens nytte. Avhandlingen slutter med følgende ord: «Der er kun en konklusion, som vor forfærdelige erfaring gir anledning til, og det er, at vi må fremtvinge vakcination. Ikke bare lægfolk, men heller ikke læger kan tilnærmelsesvis gjøre sig den forestilling om at den lidelse og elendighet, som vi var vidne til. De meget faa læger, som benytter sig av anledningen til at besøke sykehusene, medgav at de aldrig kunde tænke sig, at barnekopper var en saa frygtelig sygdom. De faa patienter, som kom sig efter at være angrepet av sygdommens værste former, lovet, skjønt de tidligere ikke hadde trodd paa vakcinationens nytte, at gaa ut og forkynde vakcinationslære fra gatehjørnene. Der var ikke en anti-vakcinationist, som ikke blev overbevist om sin vranglære ved at se denne uhørte lidelse. Endog vi, som ser og tidligere har set barnekopper, hadde aldrig drømt om at bli 
vidne til det, som vi nu saa. Det var en rødselsfuld oplevelse, og vi haaber bare, at vakcinationen blir saa almindelig utbredt, at vi aldrig mere maa bli vidne til et slikt syn.»

P.M. Holst.

Publisert: 28. juni 2021. Tidsskr Nor Legeforen. DOI: 10.4045/tidsskr.21.0297

(C) Tidsskrift for Den norske legeforening 2020. Lastet ned fra tidsskriftet.no 